\title{
Igneous seismic geomorphology of buried lava fields and coastal escarpments on the Vøring volcanic rifted margin
}

\author{
Sverre Planke ${ }^{1}$, John M. Millett ${ }^{2}$, Dwarika Maharjan ${ }^{3}$, Dougal A. Jerram4 ${ }^{4}$ Mohamed Mansour Abdelmalak ${ }^{5}$, \\ Audun Groth ${ }^{6}$, Jasper Hoffmann ${ }^{7}$, Christian Berndt ${ }^{7}$, and Reidun Myklebust ${ }^{8}$
}

\begin{abstract}
Voluminous igneous complexes are commonly present in sedimentary basins on volcanic rifted margins, and they represent a challenge for petroleum explorationists. A $2500 \mathrm{~km}^{2}$ industry-standard 3D seismic cube has recently been acquired on the Vøring Marginal High offshore mid-Norway to image subbasalt sedimentary rocks. This cube also provides a unique opportunity for imaging top- and intrabasalt structures. Detailed seismic geomorphological interpretation of the top-basalt horizon, locally calibrated with high-resolution P-Cable wide-azimuth data, reveals new insight into the late-stage development of the volcanic flow fields and the kilometer-high coastal Vøring Escarpment. Subaerial lava flows with compressional ridges and inflated lava lobes cover the marginal high, with a comparable structure and size to modern subaerial lava fields. Pitted surfaces, likely formed by lava emplaced in a wet environment, are present in the western part of the study area near the continent-ocean boundary. The prominent Vøring Escarpment formed when eastward-flowing lava reached the coastline. The escarpment morphology is influenced by preexisting structural highs, and these highs are locally bypassed by the lava. Volcanogenic debris flows are well-imaged on the escarpment horizon, along with largescale large slump blocks. Similar features exist in active volcanic environments, e.g., on the south coast of Hawaii. Numerous postvolcanic extensional faults and incised channels cut into the marginal high and the escarpment, and we found that the area was geologically active after the volcanism ceased. In summary, igneous seismic geomorphology and seismic volcanostratigraphy are two very powerful methods to understand the volcanic deposits and development of rifted margins. Our study demonstrates great promise for further understanding the igneous development of offshore basins as more high-quality 3D seismic data become available.
\end{abstract}

\section{Introduction}

There have been major improvements in the intra- and subbasalt imaging of basalt and subbasalt sequences in volcanic basins over the past few decades (Abdelmalak et al., 2015, 2016a, 2016b). These improvements have largely been obtained by developments in seismic processing, in particular by better velocity control, removal of coherent noise such as peg-leg multiples and converted waves, and broadband processing. The advances in processing have been accompanied by improvements in seismic acquisition, including the application of new source and receiver technologies and 3D data acquisition in volcanic terrains. The interpretation of volcanic sequences has also improved with the increased availability of high-quality seismic data and fieldwork on analog seismic-scale outcrops (Jerram et al., 2009; Planke et al., 2015; Schofield et al., 2016), as well as an understanding of the petrophysics of the volcanic rocks from borehole core and wireline data (Planke et al., 1999; Japsen et al., 2004; Nelson et al., 2009; Watton et al., 2014; Millett et al., 2015). With these advances in our understanding of volcanic margins, targeted 3D seismic data over key volcanic areas will provide valuable insights into how these margins develop through time

\footnotetext{
${ }^{1}$ Volcanic Basin Petroleum Research (VBPR), Oslo, Norway and University of Oslo, The Centre for Earth Evolution and Dynamics (CEED), Oslo, Norway. E-mail: planke@vbpr.no.

${ }^{2}$ Volcanic Basin Petroleum Research (VBPR), Oslo, Norway and University of Aberdeen, Department of Geology and Petroleum Geology, Aberdeen, UK. E-mail: john.millett@vbpr.no.

${ }^{3}$ Volcanic Basin Petroleum Research (VBPR), Oslo, Norway. E-mail: dwarica@vbpr.no.

${ }^{4}$ DougalEARTH Ltd., Solihull, UK and University of Oslo, The Centre for Earth Evolution and Dynamics (CEED), Oslo, Norway. E-mail: dougal@ dougalearth.com.

${ }^{5}$ University of Oslo, The Centre for Earth Evolution and Dynamics (CEED), Oslo, Norway. E-mail: m.m.abdelmalak@geo.uio.no.

${ }^{6}$ Statoil, Oslo, Norway. E-mail: augr@statoil.com.

${ }^{7}$ GEOMAR Helmholtz Centre for Ocean Research Kiel, Kiel, Germany. E-mail: jasper_hoffmann@hotmail.de; cberndt@geomar.de.

${ }^{8}$ TGS, Asker, Norway. E-mail: reidun.myklebust@tgs.com.

Manuscript received by the Editor 30 September 2016; revised manuscript received 7 March 2017; published ahead of production 1 May 2017; published online 05 July 2017. This paper appears in Interpretation, Vol. 5, No. 3 (August 2017); p. SK161-SK177, 12 FIGS.

http://dx.doi.org/10.1190/INT-2016-0164.1. @ 2017 Society of Exploration Geophysicists and American Association of Petroleum Geologists. All rights reserved.
} 
and are preserved in the offshore rock record. A highquality 3D seismic volume and a high-resolution wideazimuth P-Cable seismic profile were recently acquired on the Vøring Marginal High on the mid-Norwegian margin (Figure 1), facilitating detailed mapping of the uppermost basalt sequence.

The Vøring Margin is a type example of a volcanic rifted margin (Abdelmalak et al., 2016a). The margin was formed by continental breakup between Norway and Greenland. Voluminous basaltic sequences were deposited on both sides of the continent-ocean boundary $(\mathrm{COB})$ during the earliest Eocene (approximately 56-53 Ma; Figure 1). Several kilometer-thick sequences of the so-called seaward-dipping reflectors (SDRs) were imaged on conventional 2D seismic profiles in the 1970s (Hinz, 1981). The SDR sequence was confirmed to be of basaltic nature in the 1980s by the kilometer-deep Ocean Drilling Program Site 642 (Eldholm et al., 1987, 1989). The seismic volcanostratigraphic method was later developed in the 1990s to study the nature, geologic history, and emplacement of extrusive volcanic rocks from 2D seismic data (Planke et al., 2000) with key volcanic facies within flood basalts also being rec- ognized from the onshore record (Jerram, 2002). The seismic volcanostratigraphic method is adapted from the concept of seismic stratigraphy (Vail and Mitchum, 1977). Initially, the top and base of the volcanic sequence are mapped. Subsequently, seismic facies units are identified and mapped and are finally interpreted in terms of volcanic facies and emplacement processes using seismic facies analysis. Several characteristic volcanic seismic facies units have been mapped on the Vøring Margin, including the subaerially emplaced SDR and Landward Flows, the coastal Lava Delta, and the subaqueous Inner Flows, Outer High, and Outer SDR (Figure 1b; Berndt et al., 2001). Numerous igneous sheet intrusions, mainly sill complexes and associated hydrothermal vent complexes, are abundant in the nearby Cretaceous sedimentary basins (Figure 1b; Planke et al., 2005). More recently, new 2D industry seismic profiles have enabled mapping of the overall structure of the volcanic complex and led to the division of the Vøring Escarpment into five segments: E1-E5 (Figure 1c; Abdelmalak et al., 2016b). The segmentation of the escarpment is largely controlled by the presence of subbasalt structural highs and basins and by the shear motion along the a)

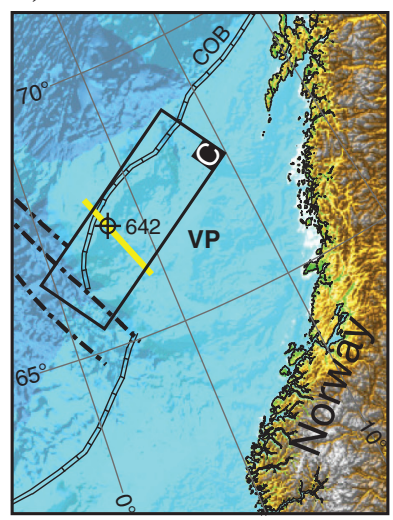

b)

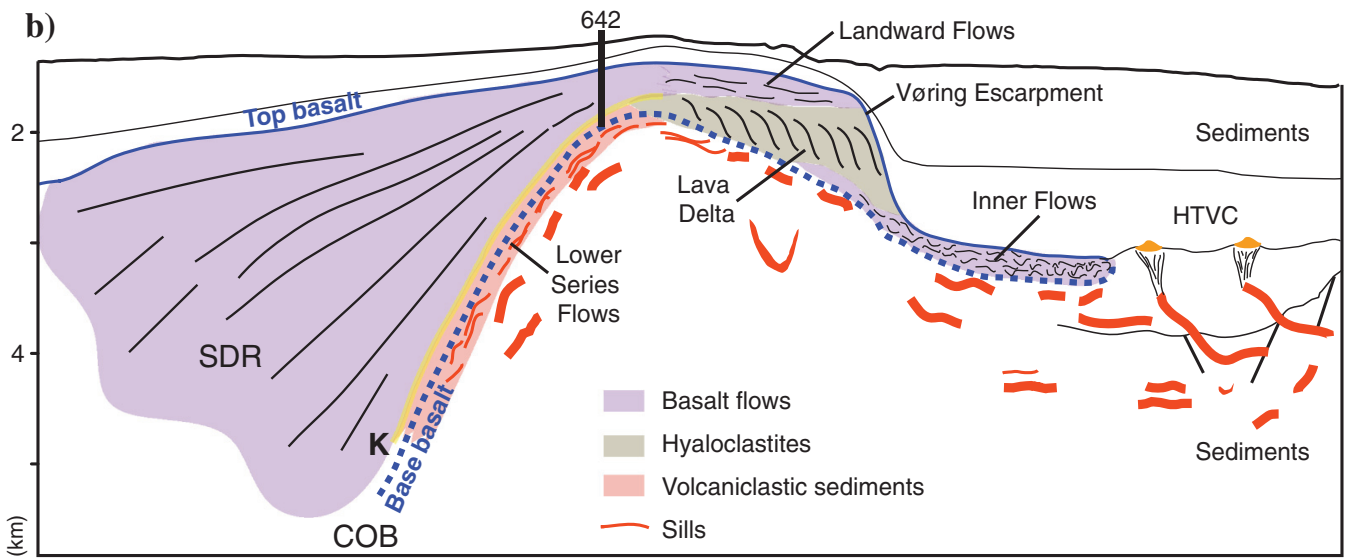

c)

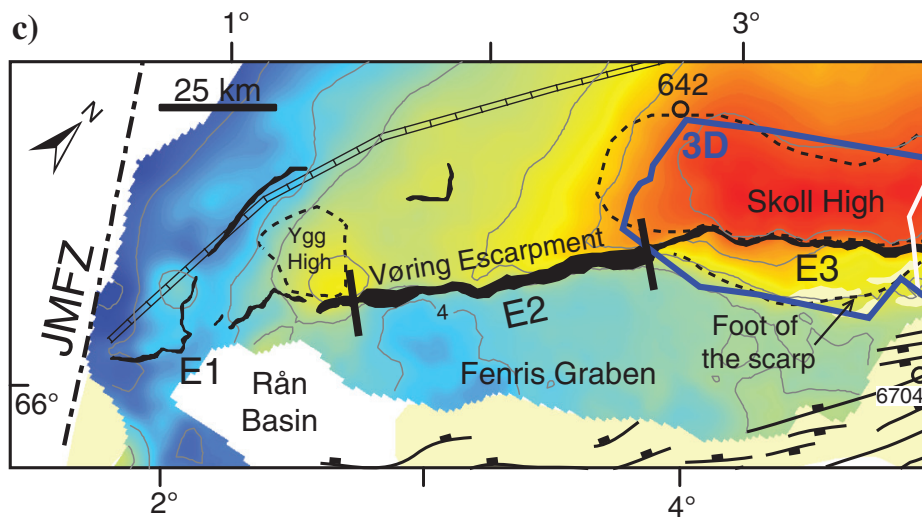

$3^{\circ}$
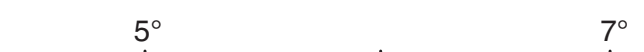

$\circ$ 
Vøring Transform Margin to the southwest. Of particular importance is the central segment E3, in which the escarpment is divided into an upper volcanic part of approximately $200 \mathrm{~m}$ high overlying a lower sedimentary part that is almost $1 \mathrm{~km}$ high. In this region, the volcanic sequence terminates against a prevolcanic structural high located along the western flank of the Fenris Basin (Figure 1c). This part of the Vøring Escarpment represents a seismic imaging window into the underlying pre-breakup age sedimentary sequences (Abdelmalak et al., 2016b).

Onshore-offshore correlation helps obtain realistic geologic and reservoir models of subsurface seismic data. This process is well-developed in sedimentary basins where the construction of reservoir models, using a variety of software packages, is common. Conversely, $3 \mathrm{D}$ onshore analog study of volcanic margins and flood basalt provinces is still in its infancy. Currently, only a handful of seismic models exist for sequences with predominantly volcanic rocks (Planke et al., 2000). However, investigations from 3D seismic data have recently highlighted the potential for using seismic attribute analysis to improve the imaging of volcanic features such as lava flows in the subsurface (Thompson, 2005; Thompson and Schofield, 2008; Schofield and Jolley, 2013). Early 3D onshore models used logged sections, mapped correlations, satellite data, correlation panels, and 3D surface mapping to construct models of flood basalt and associated sedimentary sequences (Jerram and Robbe, 2001; Single and Jerram, 2004). More recently, the use of 3D LIDAR surveying along with high-resolution 3D photogrammetric methods has revolutionized field-based 3D surface mapping allowing rapid, high-precision 3D models to be created with relative ease (Nelson et al., 2011; Stevenson et al., 2011; Eide et al., 2017).

A $2500 \mathrm{~km}^{2}$ 3D seismic cube was acquired on the central part of the Vøring Marginal High by the petroleum industry in the early 2010 s to image potential subbasalt exploration targets (Figure 1). However, these data also enable a detailed 3D interpretation of the top, base, and intrabasalt reflections. The aim of this paper is to study the igneous seismic geomorphology of the top-basalt horizon to better understand the late-stage volcanological development of the Vøring Marginal High and the Vøring Escarpment. The top-basalt surface is complex, consisting of primary volcanic deposits subsequently modified by weathering, erosion, and deposition of volcanogenic sediments. Seismic geomorphology is described by Posamentier et al. (2007) as "the application of analytical techniques pertaining to the study of landforms and to the analysis of ancient, buried geomorphological surfaces as imaged by 3D seismic data." Igneous seismic geomorphology is defined here as the study of igneous systems (deposits and processes) using 3D seismic images in map view. The geomorphological interpretation is complemented by fieldwork and satellite imagery to gain new insight into the volcanological nature of the seismic observations.

\section{Volcanological framework}

A generalized model for the development of volcanic rifted margins, such as the type and distribution of key facies, has been generated from onshore studies (Figure 2). This model considers the evolution of a volcanic margin from onset of initial volcanism to the final rifting phases (Jerram, 2015). The best-known offshore analog is the volcanic margin of Norway, where the key volcanic seismic facies have been mapped out in detail (Planke et al., 2000; Berndt et al., 2001; Abdelmalak et al., 2016a, 2016b). Integrating onshore and offshore observations through a robust conceptual model comprises a powerful approach for igneous seismic geomorphology.

Initial flood basalt volcanism commonly occurs in a sedimentary basin environment, forming shallow intrusions, peperites, or hydrovolcanic deposits generated by magma-wet sediment interaction, with subaerial lava flows occurring on basin margins and basinal highs (Planke et al., 2000; Wright et al., 2012). Continued flood basalt volcanism leads to more effusive, subaerial volcanism in which lavas progressively in-fill topographic lows and basins (Millett et al., 2015). If lava reaches an existing shoreline, then it will fragment in contact with water, constructing a foreset bedded lava delta consisting of hyaloclastites and locally massive flows (Skilling, 2002; Watton et al., 2013). The low strength of these deposits (Schiffman et al., 2006) and the high-energy coastal environment lead to extensive erosion, slumping, formation of regional escarpments, and deposition of volcaniclastic sediments by gravity mass flows (Cannon and Bürgmann, 2001).

The 3D conceptual model in Figure 2 explains the known volcanic seismic facies units (e.g., Inner Flows, Lava Delta, and Landward Flows as labeled in Figures 1 and 2). In this scenario, the Inner Flows represent an aggradational bottom set consisting of volcaniclastic sediments mixed with pillow-basalt and massive sheet flows (Nehyba and Nyvlt, 2015). Lava deltas are recognized by prograding internal architecture (Wright et al., 2012), whereas the Landward Flows form sheets of stacked subaerial lavas, which transition into Lava Delta facies at the escarpment (Figure 2).

During and after active volcanism, the erupted volcanic material may be modified by erosion and tectonic processes. Subaerial lava sequences will commonly be associated with fissure faults and ridges caused during emplacement and rifting (Opheim and Gudmundsson, 1989). These not only may be further used by later structural movements, but they may also influence the development of drainage systems (Schofield and Jolley, 2013). When lava deltas reach significant thickness, erosion and slumping may play important roles for the final morphology of parts of the escarpment (Jerram et al., 2009; Wright et al., 2012; Abdelmalak et al., 2016b). The key to the study of the igneous seismic geomorphology is to investigate the primary volcanic and secondary structural/erosional elements of volcanic terrains to de- 
velop the best possible model of the subsurface geology and the volcanic emplacement environment.

\section{Data and methods}

The main data available for this study are the 3D seismic cube CVX1101 acquired in exploration license PL527 for Chevron Norge. The data were acquired and processed by CGG Veritas. Acquisition was done using two $4980 \mathrm{in}^{3}$ flip-flop air-gun sources with a $25 \mathrm{~m}$ shotpoint interval and recorded on twelve $8 \mathrm{~km}$ streamers with $100 \mathrm{~m}$ streamer separation. Processing was completed in 2013, and time and depth cubes were available for this study. The cube covers $2500 \mathrm{~km}^{2}$, with a $25 \times 12.5 \mathrm{~m}$ inline and crossline bin size. The data were released after the license was relinquished in 2015.

In addition, one P-Cable high-resolution wide-azimuth seismic profile was included in this study (Planke and Berndt, 2007). This profile was acquired by the WGP Survey in 2015 using a $300 \mathrm{in}^{3}$ source and a $12.5 \mathrm{~m}$ shotpoint interval and recorded on sixteen $25 \mathrm{~m}$ long streamers with $12.5 \mathrm{~m}$ streamer separation. The data were processed by TGS in 2015 as a $2 \mathrm{D}$ wideazimuth stacked seismic profile. Subsequently, a 90 $100 \mathrm{~m}$ wide $3 \mathrm{D}$ swath volume with bin spacing of $3.125 \mathrm{~m}$ was processed at GEOMAR including 2D time migration using the velocities determined for the CVX1101 cube. The processed P-Cable cube is approximately $70 \mathrm{~km}$ long. The bandwidth of the data at the top-basalt level is approximately $10-320 \mathrm{~Hz}$ at the $-20 \mathrm{~dB}$ level, compared with a bandwidth of $3-90 \mathrm{~Hz}$ for the conventional $3 \mathrm{D}$ data.
The time and depth cubes were interpreted using DUG Insight software, but most of the figures in this paper are from the depth cube. Several seismic horizons were initially picked, such as the seafloor, AA, top basalt, base basalt, and sills. The horizons were picked using manual hunt, with the seafloor, top basalt, and sills following reflection peaks, and AA and the base basalt following reflection troughs. Interpretation was undertaken every 25 crosslines, along with key inlines. The interpretation was then propagated and interpolated to complete the horizon picking. The focus of this paper is the top-basalt reflection. On a broad scale, this horizon is easily identified as a high-amplitude peak in the data, defining the Vøring Marginal High, the Vøring Escarpment, and the Inner Flows region (Figure 3). However, detailed picking of the horizons for high-resolution studies was more challenging, in particular in which the top basalt was faulted or eroded. Another challenge was to pick the top of the volcanic deposits in areas where this surface was potentially buried by volcanogenic sediments. The improved high-resolution vertical and spatial imaging of the top-basalt reflection in the P-Cable data (Figure 3b) was used to guide the detailed picking of the horizon.

The interpretation of the volcanic sequence followed the seismic volcanostratigraphic approach of Planke et al. (2000). The volcanic sequence boundaries were defined by the top- and base-basalt reflections. Four main seismic facies units were identified in the study area: the (1) SDR, (2) Landward Flows, (3) Lava Delta, and (4) Inner Flows (Figure 3a). Subbasalt igneous

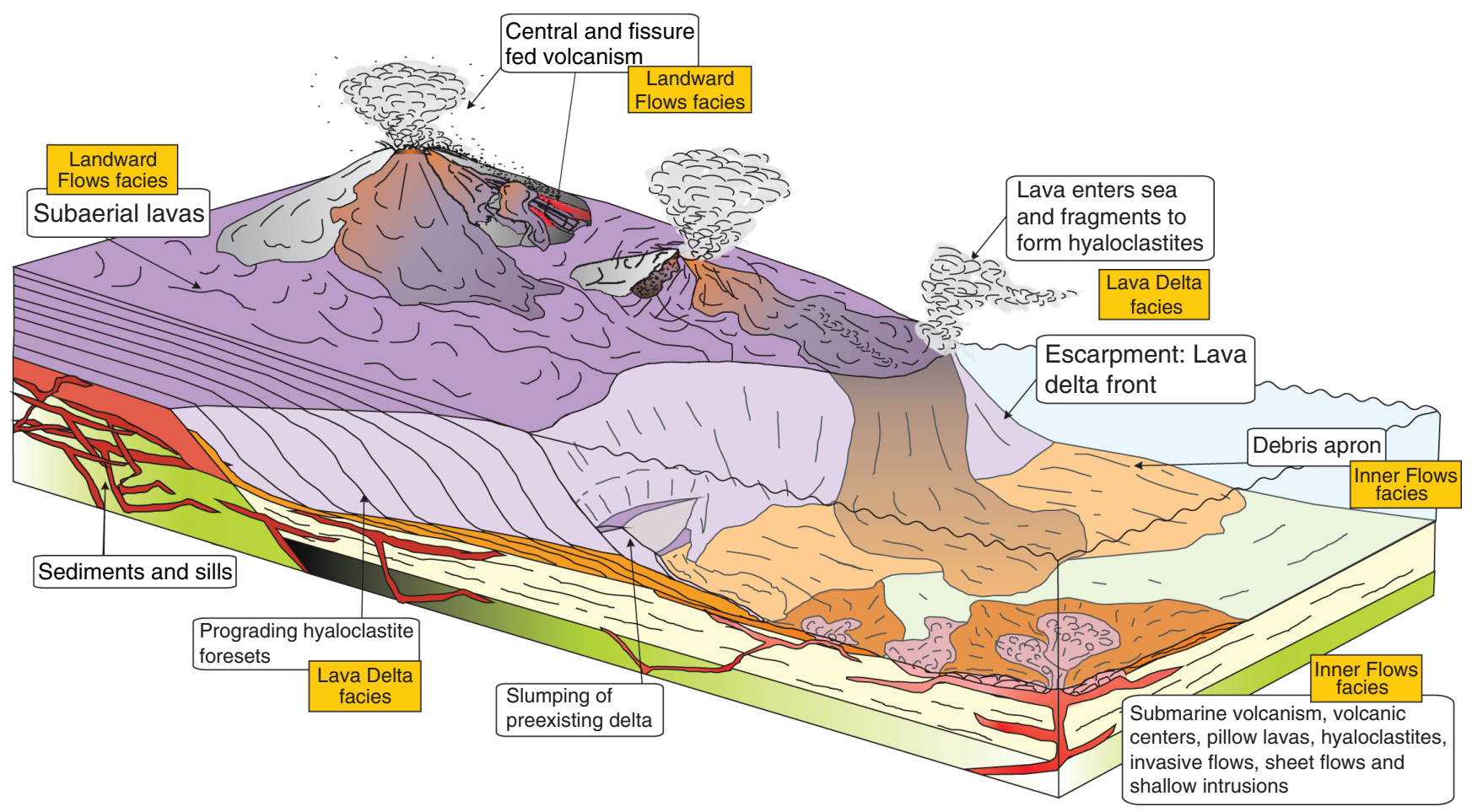

Figure 2. Sketch of volcanic processes and deposits relevant for the Vøring Margin breakup volcanism. Characteristic volcanic seismic facies units (e.g., Inner Flows and Lava Delta) are labeled. 
sheet intrusions were interpreted below the volcanic sequence using the methods of Planke et al. (2015). The interpreted sills are characterized by relatively high-amplitude, low-frequency saucer-shaped reflections with abrupt terminations.

Additional seismic volume and horizon attributes were calculated to assist the interpretation and visualization of the data. Similar analysis has proven effective for visualizing lava flow and drainage characteristics on subsurface volcanic surfaces (Schofield and Jolley, 2013). The variance cube is useful for visualization and interpretation of steeply dipping boundaries such as faults. Root-mean-square (rms) amplitudes were calculated for the top-basalt horizon, using windows of $15 \mathrm{~m}$ above and below (rms 30) and $15 \mathrm{~m}$ above and $50 \mathrm{~m}$ below (rms 65) the horizon. The different horizon and volume attributes were coblended in DUG software. The horizon depth or rms amplitude data were blended with the variance cube, making only the low coherency values visible as dark gray shades on top of the colored and rendered depth or amplitude data (Figure 4).
The top-basalt horizon was studied using the seismic geomorphological approach of Posamentier et al. (2007). Geomorphology is the study of the origin and evolution of the earth's surface, whereas seismic geomorphology is the study of buried surfaces imaged in 3D seismic data. In this paper, we focus on the volcanological study of the top-basalt horizon to understand the igneous nature and origin of this seismic horizon. The coblended rms amplitude and coherency data were particularly useful for this igneous seismic geomorphological study (Figure 4b).

\section{Marginal high surface}

Volcanic landscapes comprise a wide range of surface features that hold information about the processes that formed them. The rms 65 top-basalt horizon envelope gives a unique opportunity to visualize the volcanic landscape that existed at the end of volcanism on the Vøring Marginal High and the Vøring Escarpment at approximately $55 \mathrm{Ma}$ ago (Abdelmalak et al., 2016b). In this section, we compare selected features from the rms 65 top-basalt horizon with field analogs from basaltic

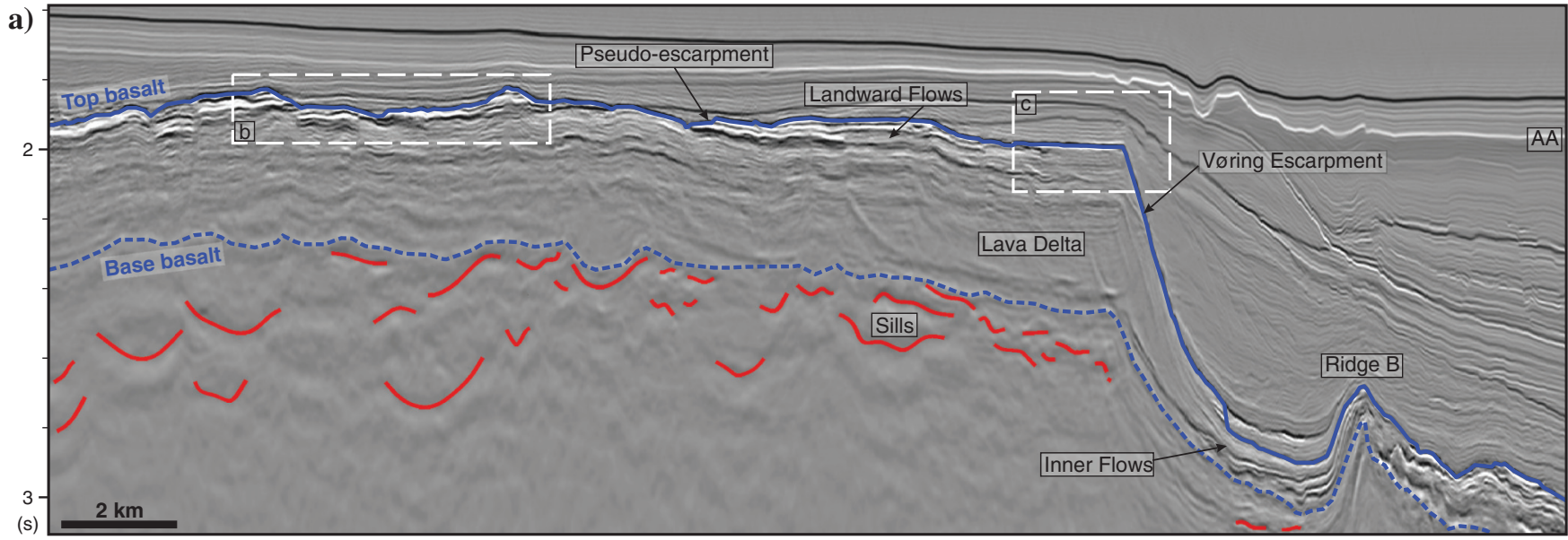

b)
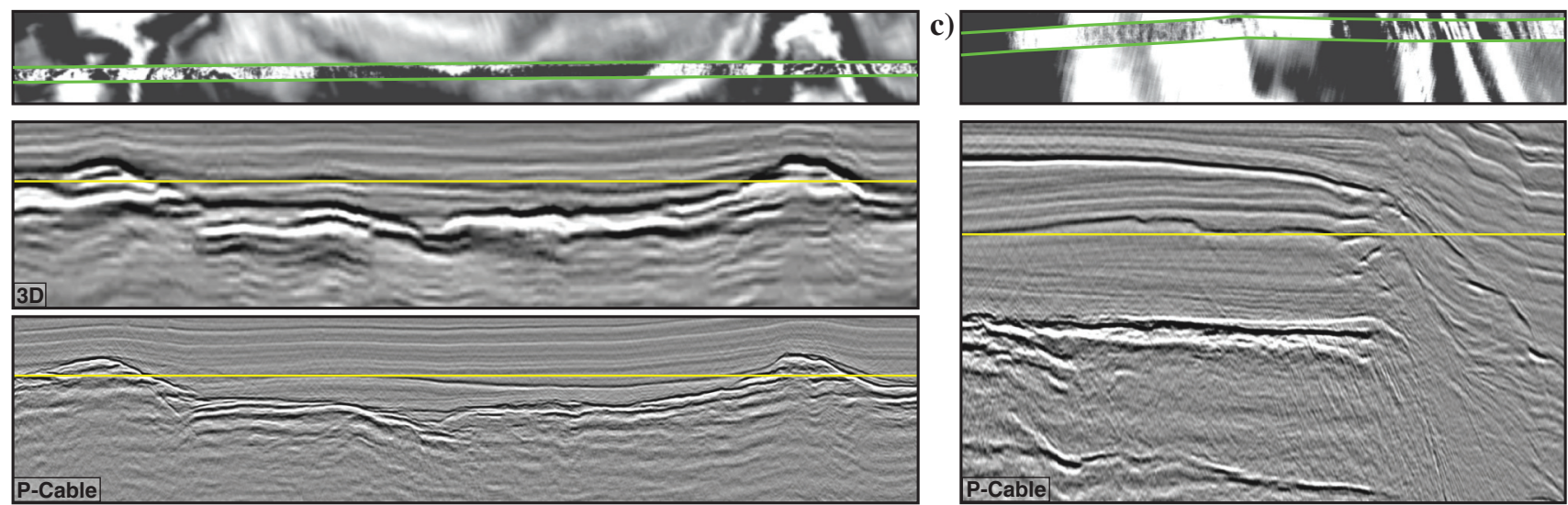

Figure 3. Seismic data examples showing typical data quality. (a) Arbitrary seismic profile across the northern part of the 3D survey with interpreted horizons. Line located in Figure 1c. (b) Comparison of conventional and high-resolution P-Cable 3D seismic data on the marginal high on time slices (the upper panel shows the $90 \mathrm{~m}$ wide P-Cable swath in green compared with conventional 3D; the depth of the time slices is marked by the yellow line below) and seismic sections. (c) Vøring Escarpment seismic example, showing comparison of P-Cable and conventional time slices (upper panel; color scheme as in b) and P-Cable seismic section (below). 
volcanic provinces around the world to establish the emplacement environment of the succession.

A fundamental building block of the subaerial part of basaltic provinces are lava flows. In Figure 5, key examples of lava flow features from the rms 65 top-basalt horizon are compared with onshore analogs from Google Earth. The lava flows from the rms 65 top-basalt horizon are delimited by their high-amplitude lobe-like margins, and they comprise a range of morphologies and scales, but they typically display lava lobes between approximately 0.5 and $2 \mathrm{~km}$ wide and thicknesses roughly interpreted to be on the order of a few tens of meters. There are several examples of curved ridges on the surfaces of lava lobe features from the rms 65 topbasalt horizon. In nature, these ridges are formed due to compression of the evolving lava crust as it cools, whereas a flow of lava continues beneath the insulating crust forming distinct compression or "ropey" ridges on a range of scales that are curved in the direction of flow (Fink and Fletcher, 1978; Gregg et al., 1998; Ball et al., 2008). Another common feature of basaltic lava flows is the development of multiple flow lobes and anastomosing channels that commonly relate to the development of flow fields fed by continuous to semicontinuous eruptions commonly lasting anywhere from days to decades. In the rms 65 top-basalt horizon, several compounds to channelized lava flows are observed (Figure 5a-5c). Depending on a range of factors such as viscosity, temperature, effusion rate, and eruption environment, lavas may undergo significant inflation resulting in the thick-

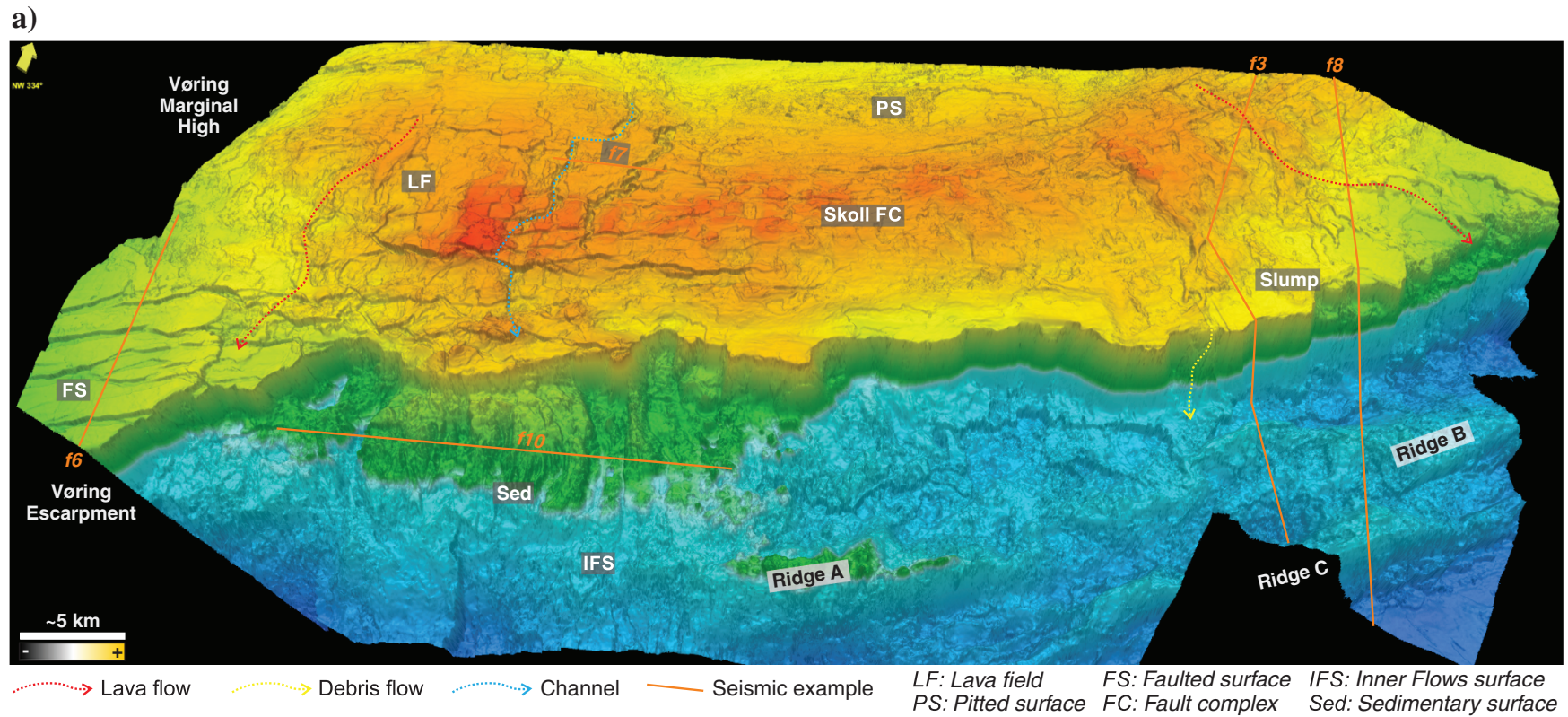

b)

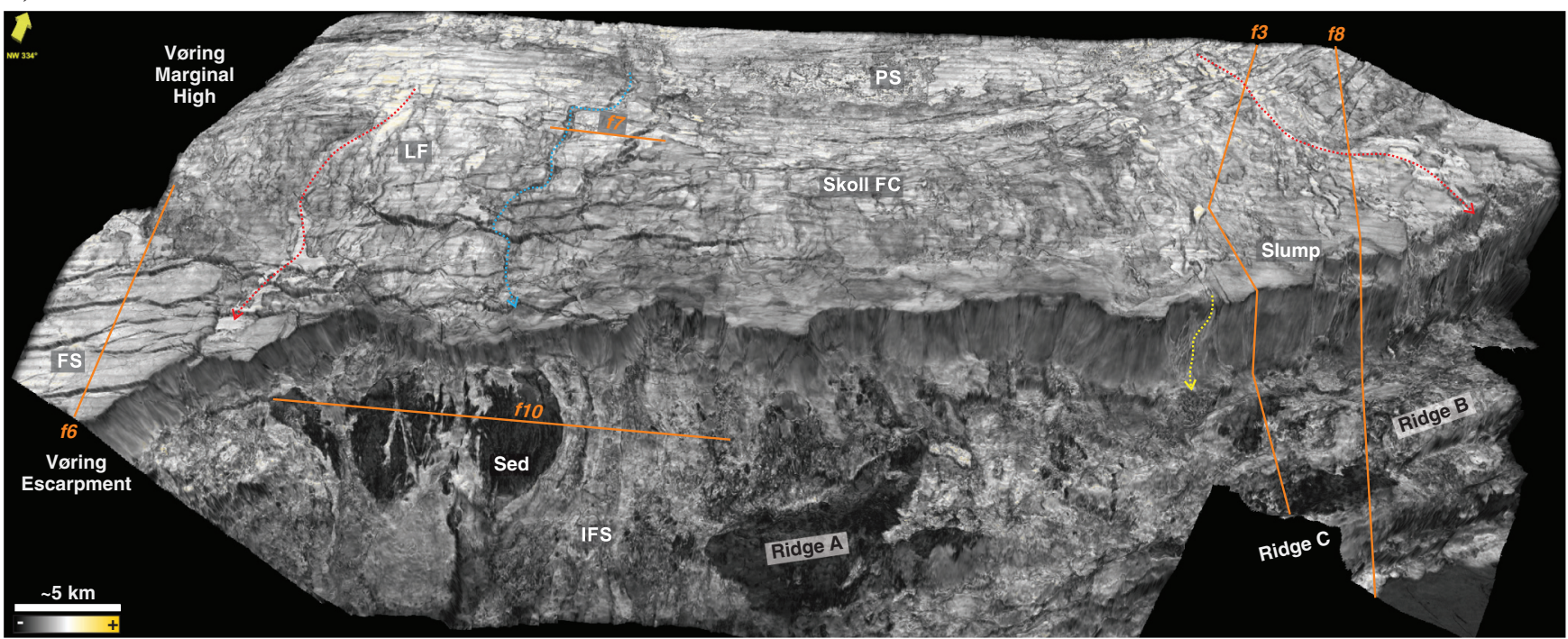

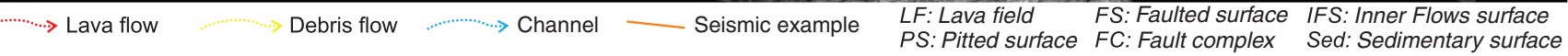

Figure 4. Perspective views of the top-basalt horizon. (a) Depth and coherency blend. (b) Top-basalt rms amplitude and coherency blend (rms 65). Seismic profiles located (f3, f8, f6, f10). 
ening of the flow lobes (Figure 5c; Hon et al., 1994; Self et al., 1996). Similar lava flow features have also been imaged within the Faroe-Shetland Basin to the southwest of the study area (Schofield and Jolley, 2013).
In the western region of the data cube, overlying the feather edge of the SDR domain, a highly pitted and irregular surface is revealed in the rms 65 top-basalt horizon (Figure 5d). The surface reflection comprises
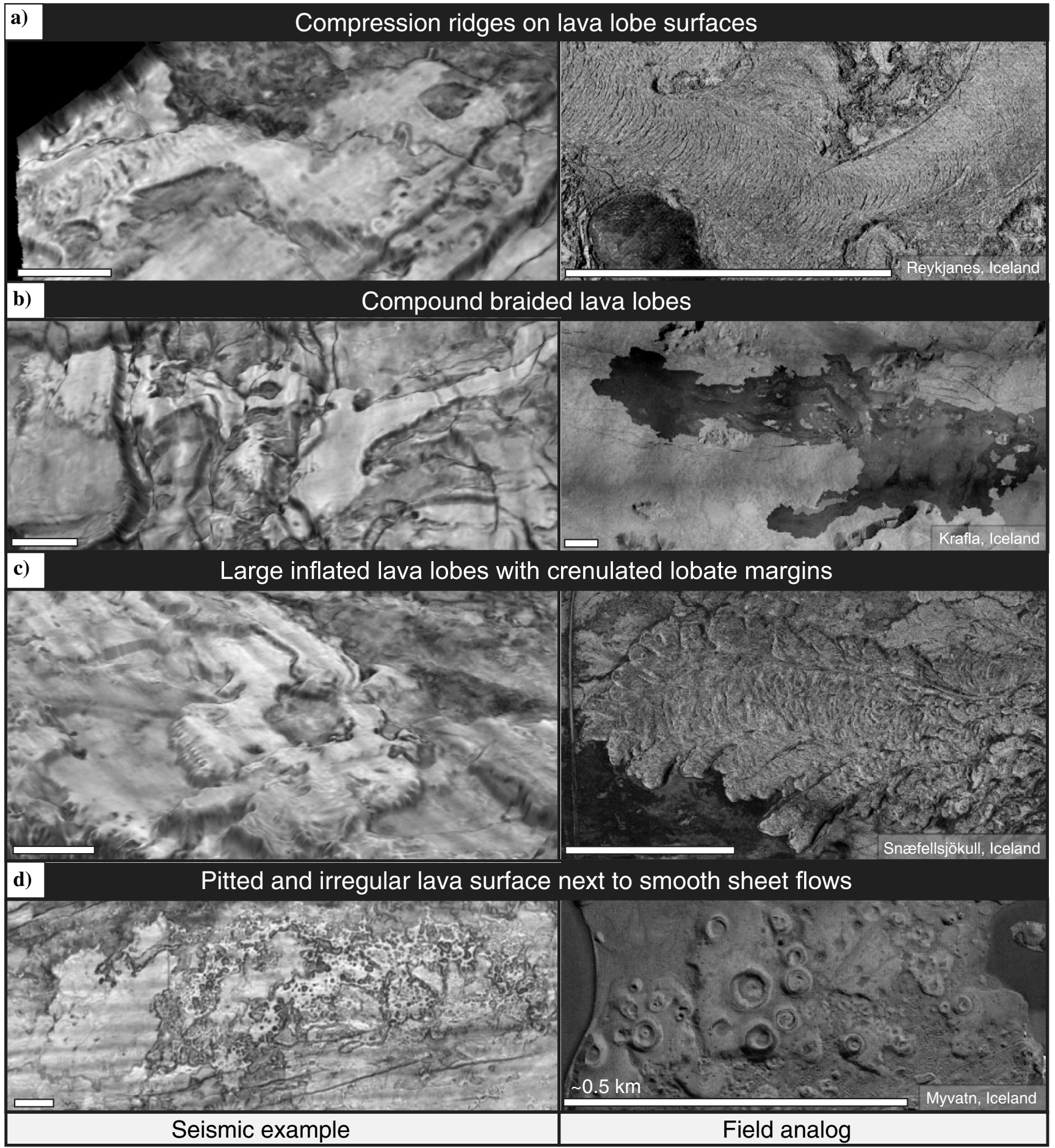

Figure 5. Comparison of seismic lava flow geomorphology of the rms 65 top-basalt horizon with field analogs. (a) Compression ridges formed on the surfaces of lava flows indicating the flow direction. (b) Compound-braided lava lobes formed by the eruption of numerous anastomosing flow lobes. (c) Large inflated flow lobes with multiple smaller lobes at margins. (d) Pitted irregular lava surfaces formed by the formation of rootless cones where lava erupts over a water-saturated substrate. All scale bars represent approximately $1 \mathrm{~km}$ unless stated otherwise. Field images are from Google Earth. 

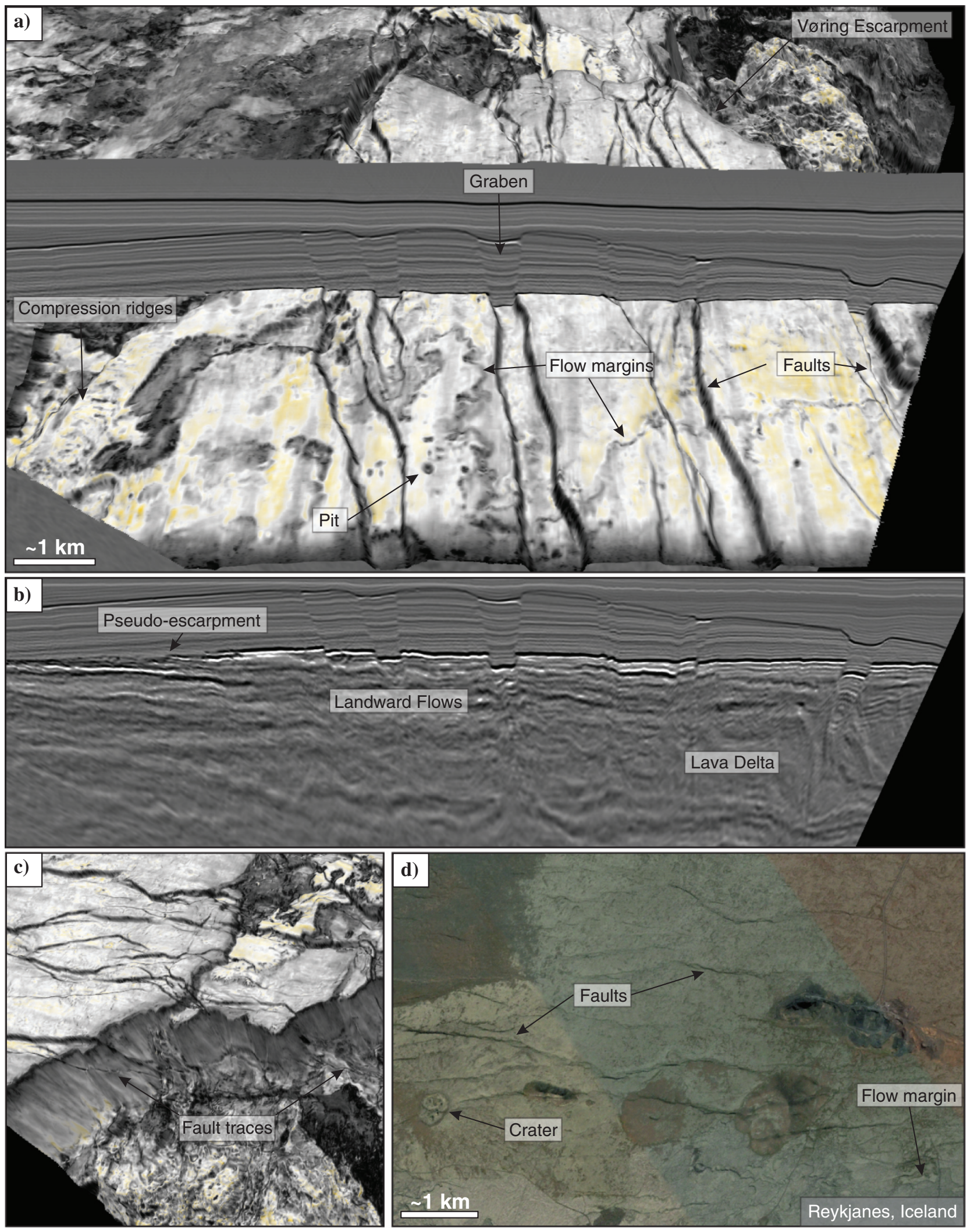

Flow margin

Figure 6. Perspective view of faulted lava fields on the rms 30 top-basalt horizon. (a) Grabens dissecting the Skoll High viewed from the south. (b) The 2D seismic line in (a) showing that the faults cut through the volcanic sequence (Landward Flows and Lava Delta). (c) Examples of faults dissecting the Vøring Escarpment and the Inner Flows. View from the north. (d) Field analog of a faulted lava field in a rift zone. The seismic profile is located in Figure 4. 
high amplitudes similar to lava flows elsewhere in the survey but with numerous subrounded to irregular pitlike features with low amplitudes. These pitted surfaces appear to grade smoothly laterally into more typical sheet-like lava features implying that they are linked. Several explanations of these features are possible from observations of volcanic terrains, such as pressure ridges or tumuli, hummocky pahoehoe surfaces, and deflation structures (Hon et al., 1994). However, perhaps the best potential analog are lava flows that have developed extensive rootless or littoral cones that form common features where lavas flow over water-saturated surfaces (Hamilton et al., 2010; Reynolds et al., 2015; Noguchi et al., 2016). Such rootless cones form from the explosive interaction between lava flowing over watersaturated sediments, lakes, rivers, or ponded water. The resulting craters are deeply excavated and partly filled with fragmental volcanic detritus. They would be expected to display reduced velocities compared with the more coherent surrounding lava flow. In Figure 5d, an example of the extensive closely spaced rootless cones at Myvatn, Iceland, is shown as a possible analog. These features are quick to erode, which would leave a pock-marked irregular landscape very similar to the rms 65 top-basalt horizon. By implication, the rms 65 topbasalt horizon features could therefore represent a lava field that interacted with a wet substrate over large areas, which is plausible given its location above the rapidly subsiding SDR domain at the seaward margin of the Vøring Marginal High (Planke et al., 2000). The development of ravinement structures elsewhere on the top basalt (see discussion below) also highlights that river systems were developing on the subaerial lava flows, and it provides clear evidence of surface water.

Perhaps one of the most striking features revealed by the rms 30 top-basalt horizon is the fault structures and associated displacements that dissect the palaeosurface (Figure 6). In Figure 6a, lava flow features similar to those highlighted in Figure 5 are observed. Clear lobate lava flow margins and possible pits are also wellimaged. Extensional faulting is observed throughout the entire study area, and there is no clear evidence of reverse faults. In Figure 6a, north-trending graben structures are imaged with a fault spacing of approximately $400-500 \mathrm{~m}$ and displacements of typically approximately $30-50 \mathrm{~m}$. In Figure 6c, the fault traces that dissect the Skoll High top-basalt surface are clearly imaged dissecting the palaeo-Vøring Escarpment surface and can be traced across the scarp and through the Inner Flows. In Figure 6d, a field analog from the faulted lava surface of the Reykjanes Peninsula rift zone is displayed.

In Figure 7a, the faulted top basalt rms 65 top-basalt horizon is visualized looking westward across the Skoll High. Clearly meandering erosional channel features are observed cutting the surface across the entire central part of the Landward Flows lava plateau. The main channels are approximately $400 \mathrm{~m}$ in width and generally approximately 30-45 $\mathrm{m}$ deep in the deepest parts. The depth of the channels appears to reduce toward the escarpment. Clear tributary channels are observed to join the main channels appearing to originate from within the plateau. At the margins of the channels, traces of terraces step back from the channel.
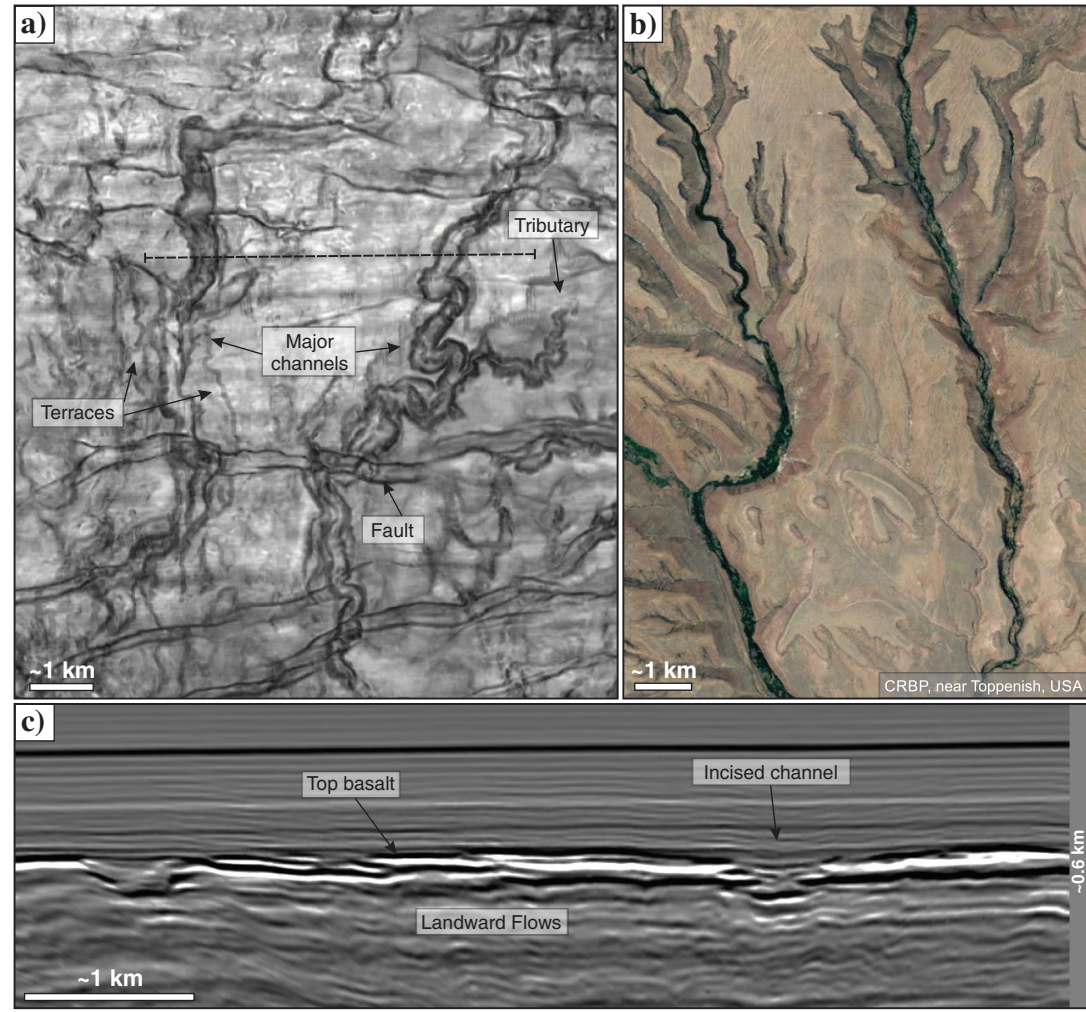

Figure 7. Examples of erosional channels cutting into the top-basalt surface. (a) Large meandering channels cutting the rms 65 topbasalt horizon. (b) Field analog from the Columbia River Basalt Province (CRBP) where erosional channels incise the lava plateau. (c) A 2D seismic line showing the discontinuous top-basalt horizon with incised channels. The line is located in Figure 4 and in (a). 
In Figure 7b, a potential analog example of two river channels cutting through the Miocene-aged Columbia River Basalt Province (CRBP) is presented. The 2D cross-sectional view of the channels is presented in Figure $7 \mathrm{c}$. The features revealed by the rms 65 top-basalt horizon display clear examples of erosional channels cutting the palaeo-Landward Flows surface. The chan- nels suggest a significant period of subaerial exposure at the end of the main phase of volcanism on the Skoll High. The scale of the drainage systems and their catchments are difficult to infer without constraints on the time it took for them to form, but they clearly demonstrate the development of drainage systems within the lava field (Schofield and Jolley, 2013; Ebinghaus et al.,

a)

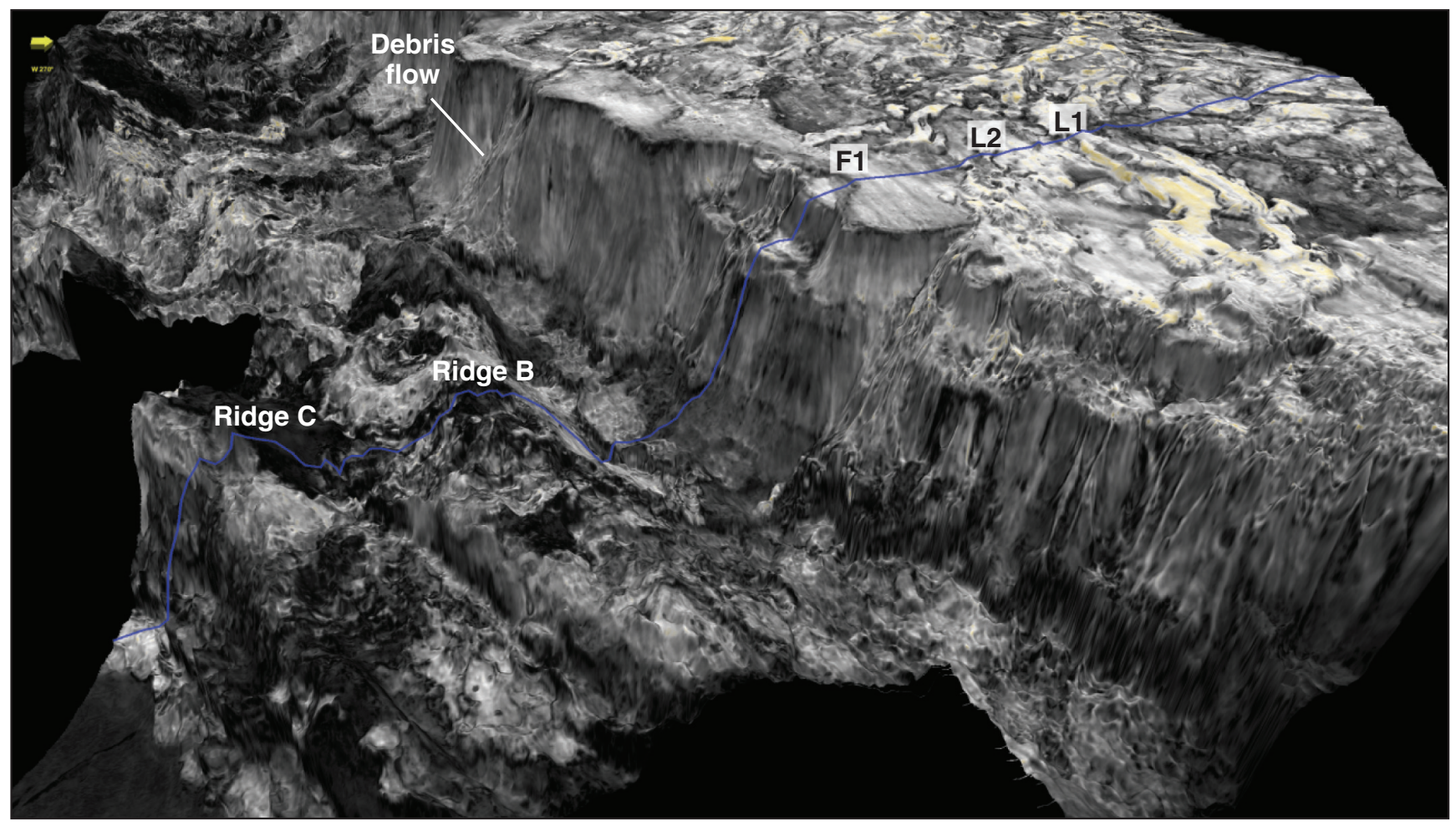

b)

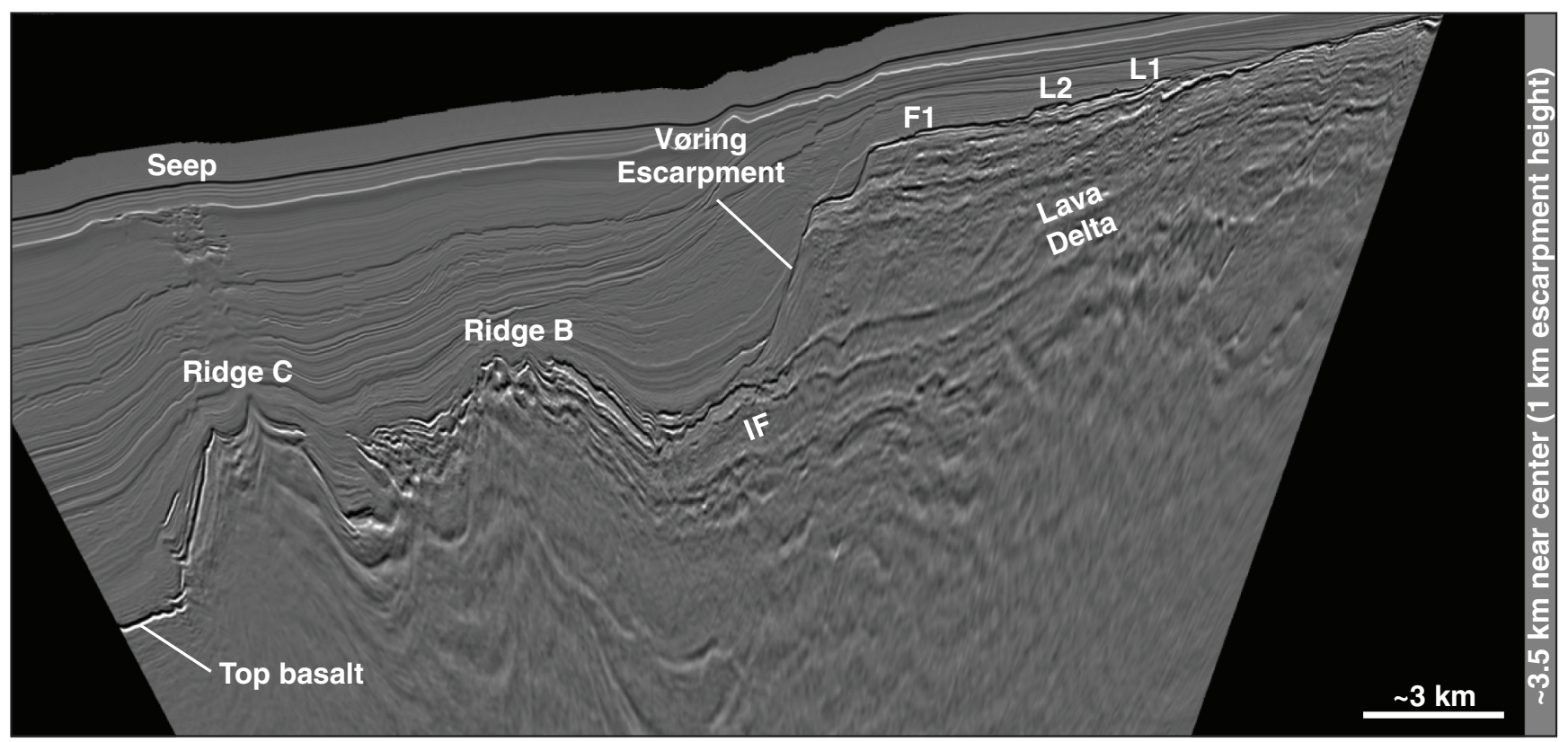

Figure 8. Igneous seismic geomorphology of the Vøring Escarpment. (a) Perspective view of the rms 30 top-basalt horizon seen from the north. (b) Seismic example along the blue line in (a). Location of fault scarp (F1) and lava flows (L1, L2) shown. IF, Inner Flows. 
2014). These channels present clear evidence for drainage systems coming from the west at this time feeding sediments into the Vøring Basin, likely in-filling the Fenris Graben.

\section{Vøring Escarpment}

The Vøring Escarpment comprises a major structural component of the Norwegian continental margin and formed a prominent topographical feature at the end of the Paleogene volcanism (Abdelmalak et al., 2016b). Figure 8 displays the rms 30 top-basalt horizon across the escarpment in the northeast part of the study area near the eastern flank of the Skoll High. A different visualization of the escarpment region is shown in Figure 9. The escarpment is generally on the order of approximately $1 \mathrm{~km}$ high with a dip of approximately $25^{\circ}-30^{\circ}$. High seismic amplitude lava flows transgress across the escarpment edge into spatially coherent aprons of highamplitude chaotic reflectors. These features are interpreted as volcanic debris flows connecting the Landward Flows domain on the marginal high with Inner Flows domain at the basin floor across the escarpment (Figures $8 \mathrm{a}$ and 9). The term "debris flows" is used as a broad description for the extrusive volcaniclastic facies

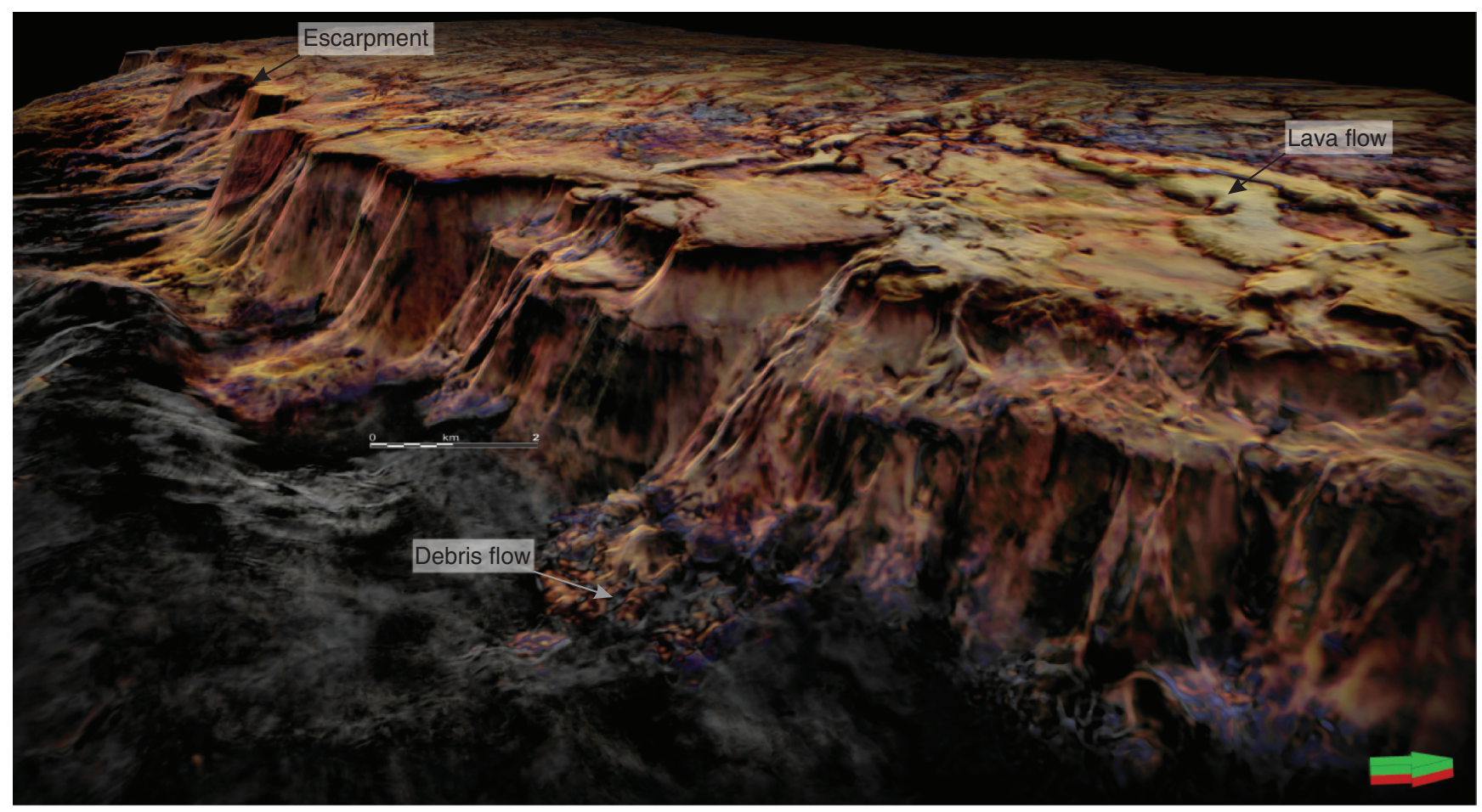

Figure 9. Perspective view of the Vøring Escarpment, looking toward the southwest. The image displays the interpreted topbasalt horizon blended with coherency data. The image reveals a well-developed subaerial lava field on the Vøring Marginal High and a prominent, approximately $1 \mathrm{~km}$ high, coastal escarpment. Volcanogenic debris flows are identified on the escarpment and spread out as lobes in the Fenris Graben. Note that the top-basalt horizon is picked at a slightly higher stratigraphic level than in Figure 8 in this part of the cube to better visualize the lower part of the debris flow. The scale bar is approximate for the central part of the figure. The image was generated using Petrel software.
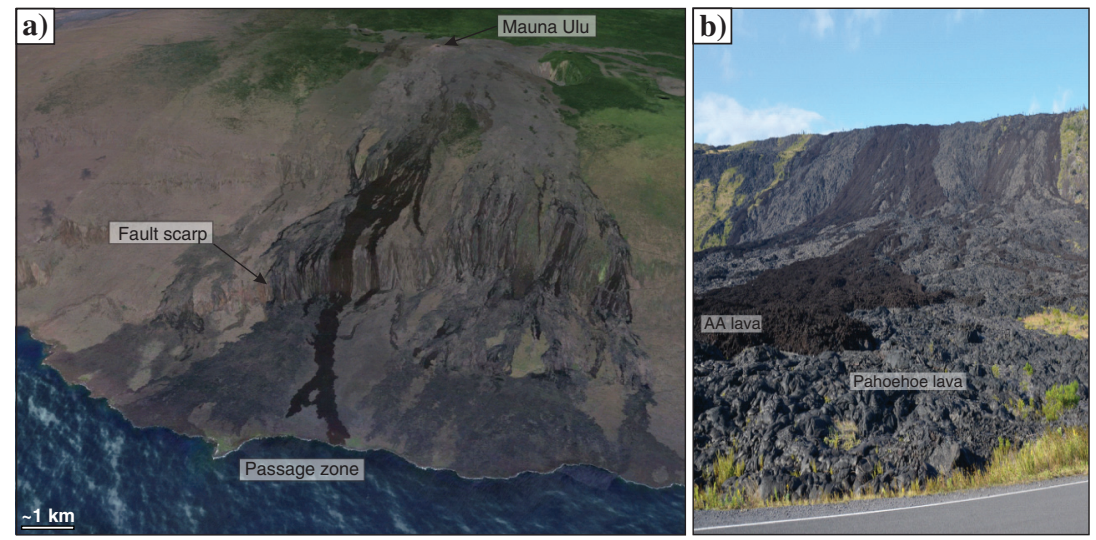

Figure 10. Analog igneous geomorphology of escarpments in Hawaii. (a) Google Earth perspective view of the southern part of Hawaii, showing fault scarps (pali) and recent lava fields. (b) Photo of recent lava flows across the fault scarp. 
a)

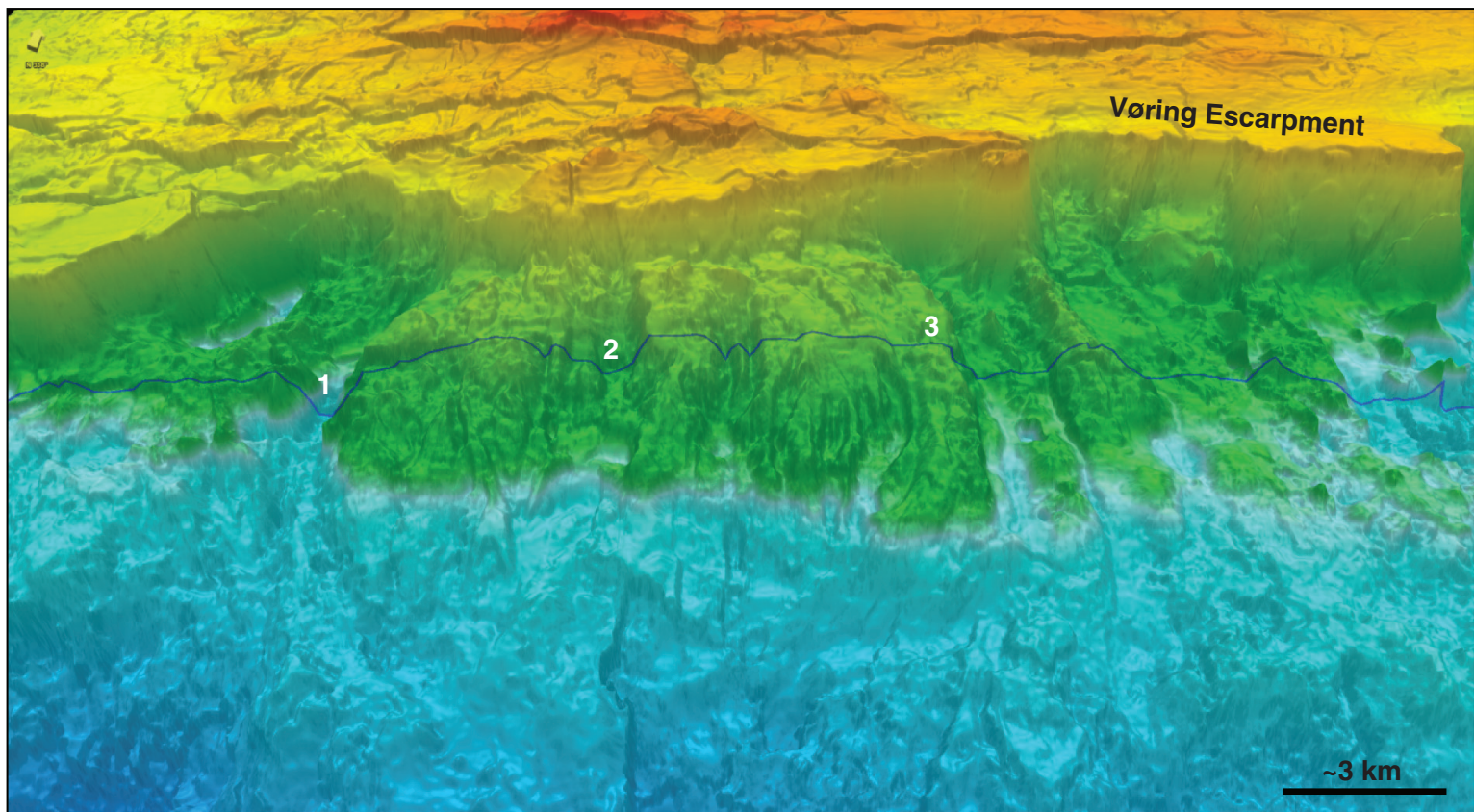

b)
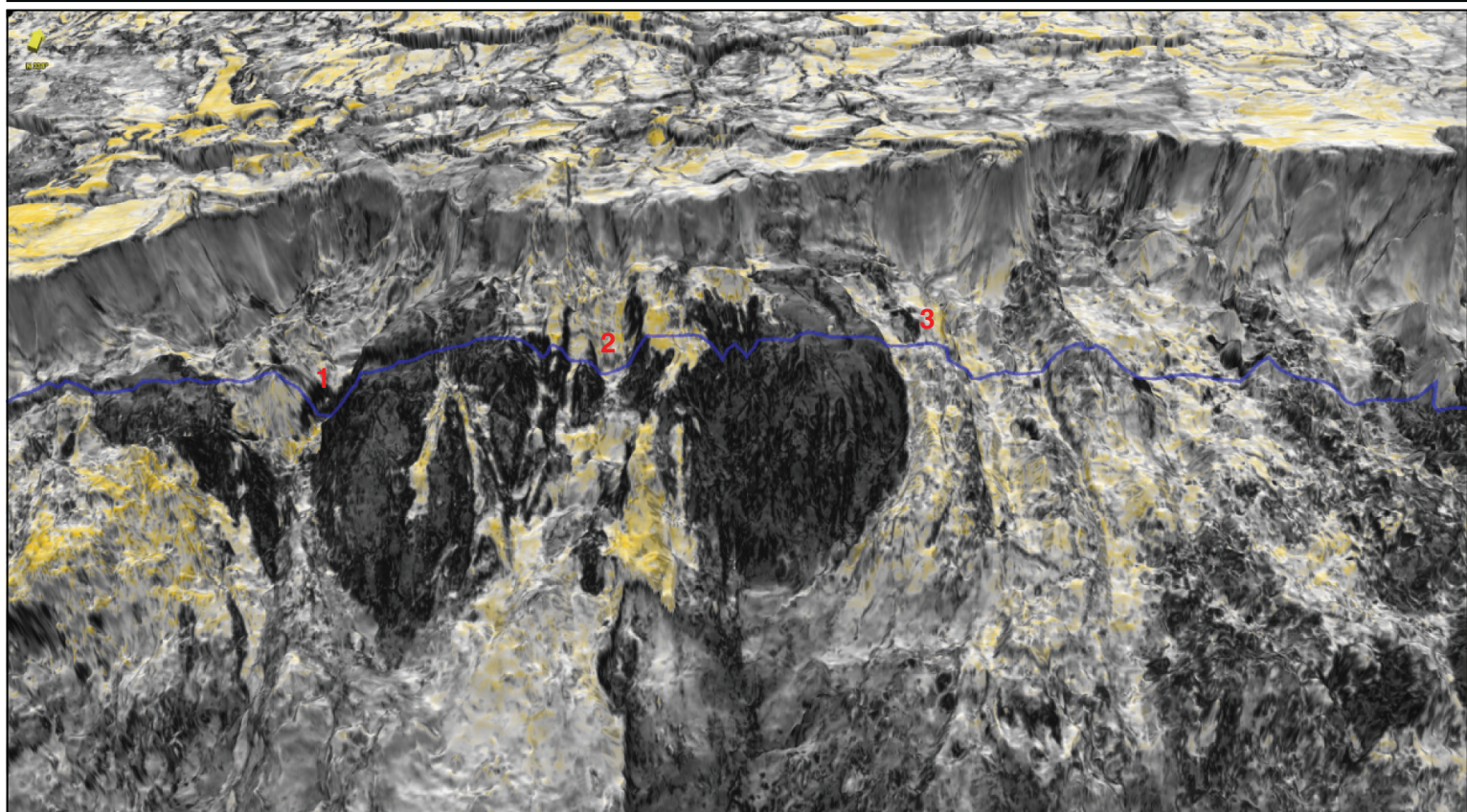

c)

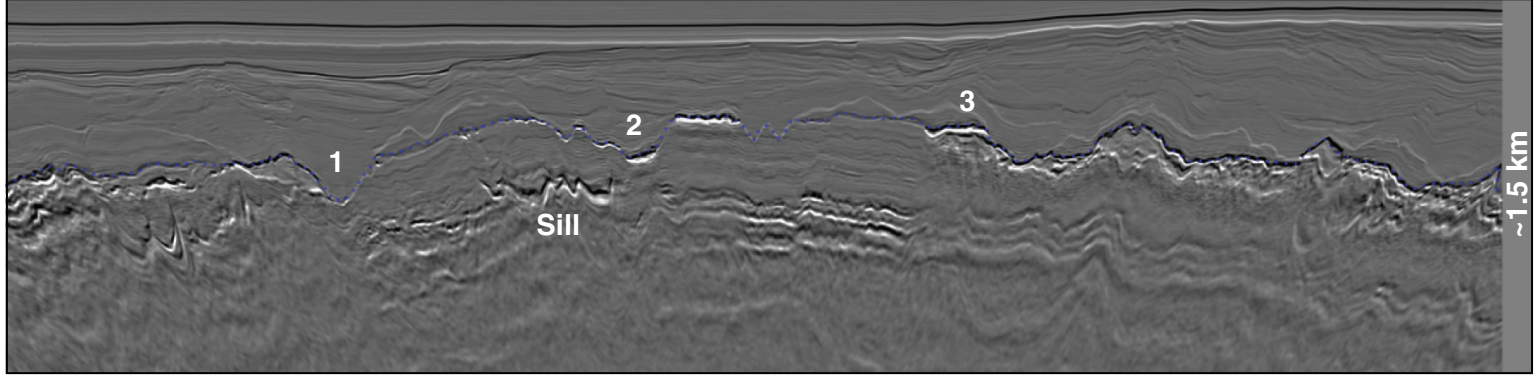

Figure 11. Perspective view of paleochannels, or valleys, across the Vøring Escarpment. (a) Depth horizon of the top basalt. (b) The rms 30 top-basalt horizon. (c) Seismic strike line along the central part of the escarpment. Profile located in Figure 4 and as blue line in Figure 10a and 10b. Numbers 1, 2, and 3 show valleys and ridges. Color scales as in Figure 4. 
that are observed to flow down the escarpment within the seismic data. In reality, these facies can be highly complex and include various hyaloclastites, pillows, and feeder tubes (Watton et al., 2013). In cross section, these surface features are clearly linked to classic rifted margin architectural features (Planke et al., 2000). Several prominent slump structures are also clearly identified at the top of the escarpment (Figure 8). The identification of debris flows draping these perched slump features demonstrates that they formed part of the palaeotopography at the time of volcanism.

The features revealed from the rms 30 top-basalt horizon show clear similarities to the present-day analogs from, e.g., Hawaii (Figure 10). In the Hawaii example, lava flows from Mauna Ulu are observed to flow down the flanks of Mauna Loa across the prominent fault scarps associated with the Hilina fault system (Cannon and Bürgmann, 2001). The faulting in the Hawaii example is related to a flank collapse of the Hawaii oceanic island; however, the volcanic features and the geomorphological similarities to the Vøring Escarpment rms 30 top-basalt horizon are striking. Lava delta deposits form highly unstable deposits that are prone to instability and collapse (Schiffman et al., 2006). In the Hawaiian example, lavas enter the ocean through the passage zone (Skilling, 2002) and transition downslope into lava delta deposits comprising hyaloclastite and pillow breccias. Evidence for extensive and complex slumping and mass wasting of the subsea escarpment is also observed from offshore bathymetric data around Hawaii (Smith et al., 1999).

In Figure 11, the depth and rms 30 top-basalt horizons across the escarpment are displayed for the central portion of the study area. The depth image displays a highly dissected escarpment surface with numerous channel-like features orientated perpendicular to the escarpment. Compared with the rms 30 top-basalt surface, several low-amplitude regions are clearly observed between, and are partly dissected by, the dominantly high-amplitude top-basalt surface. These low-amplitude regions are interpreted to represent subcropping prevolcanic sedimentary units comprising a correlative unconformity to the top-basalt surface. This interpretation is supported by the 2D seismic line presented in Figure 11c. The low-amplitude regions are only observed below approximately $200 \mathrm{~m}$ from the top of the escarpment. Along with evidence from Figure 3a, this $200 \mathrm{~m}$ interval is interpreted to represent the thickness of the erupted lava sequence in this part of the Skoll High. It should be noted that the thickness of the lavas capping the Vøring Marginal High increases away from the Skoll High to the northeast and southwest. A present-day terrestrial example of a deeply eroded volcanic topped escarpment is presented in Figure 12. Although this forms a subaerial setting, the scale and general geomorphology of the basalt-capped escarpment show clear similarities to the Vøring Escarpment surface.

A striking feature of the rms 30 top-basalt horizon in Figure $11 \mathrm{~b}$ is the relationship between the high-amplitude volcanic facies and the incised escarpment surface. Thin channelized volcanic debris flow facies are observed to flow down the channels on the escarpment surface but are also clearly deflected around the topographic highs formed by the sedimentary subcrops. These lava-fed debris flows clearly postdate the incised channels on the palaeoescarpment surface and therefore represent late-stage eruptions flowing across the Skoll High. The channelized lava debris flows are clearly observed to spread out into wider sheet-like surfaces at the base of the escarpment. It is possible that these features not only represent the fanning of volcaniclastic debris, but they may also represent subaqueous sheet flows (Batiza and White, 2000) potentially connected to the subaerial Skoll High feeder lavas by lava tubes (Watton et al., 2013).

\section{Conclusions}

This igneous seismic geomorphological study of the top-basalt horizon on a recently acquired 3D seismic cube on the central Vøring Marginal High reveals new documentation and insight into the late-stage development of an approximately $55 \mathrm{Ma}$ old voluminous volcanic sequence. The unique, high-quality cube was interpreted by detailed seismic picking of the top-basalt horizon. The accuracy of the horizon interpretation was enhanced using a high-resolution P-Cable wide-azimuth profile through the cube. The $3 \mathrm{D}$ data were visualized in 
combination with horizon and volume attributes to enhance the volcanological imaging.

The seismic data in conjunction with fieldwork and satellite imagery revealed for the first time extensive subaerial lava flow fields, lava flows with compressional ridges and inflated lava lobes, and pitted lava surfaces likely formed in a wet environment. The lava fields were subsequently intensively faulted to form graben structures incised by channels transporting sediments into the Fenris Graben.

The steeply dipping $\left(25^{\circ}-30^{\circ}\right)$ kilometer-high Vøring Escarpment was formed by the complex interaction of volcanological and sedimentological processes. Subaerial lava flows are imaged where they entered the sea at the top of the escarpment, with spectacularly well-imaged volcanogenic debris flows deposited downward on the escarpment and on the basin floor. Locally, slump blocks are well-defined in the seismic data.

The escarpment is composed of volcanic sequences and prevolcanic sediments in the southern part of the cube. Here, an almost $1 \mathrm{~km}$ thick sedimentary sequence, forming a structural high at the time of volcanism, is incised by several channels. Some of these channels were later used by subaqueous lava flows. The morphology of the escarpment is very similar to onshore active volcanic environments in Hawaii and inactive great escarpments in South Africa. This suggests that - at least during the late stage of volcanism - the emplacement of flood basalt provinces was governed by the same eruption and flow mechanisms as modern volcanic systems. The major channel systems cutting the top basalt and the escarpment surfaces have implications for sediment (possibly siliciclastic) supply and entry points into the outer Vøring Basin.

This study identifies useful workflows for the interpretation of volcanic deposits in seismic data. We argue that igneous seismic geomorphology, when used in conjunction with seismic volcanostratigraphy, represents the state-of-the-art approach to extract volcanological insights from 3D seismic data.

\section{Acknowledgments}

We are very grateful for P-Cable data access from TGS and VBPR. We further acknowledge the support from the Research Council of Norway through its Centres of Excellence funding scheme, project 22372. Constructive editorial and anonymous reviews are also greatly appreciated.

\section{References}

Abdelmalak, M. M., T. B. Andersen, S. Planke, J. I. Faleide, F. Corfu, C. Tegner, G. E. Shephard, D. Zastrozhnov, and R. Myklebust, 2015, The ocean-continent transition in the mid-Norwegian Margin: Insight from seismic data and an onshore Caledonian field analogue: Geology, 43, 1011-1014, doi: 10.1130/G37086.1.

Abdelmalak, M. M., R. Meyer, S. Planke, J. I. Faleide, L. Gernigon, J. Frieling, A. Sluijs, G.-J. Reichart, D. Zas- trozhnov, S. Theissen-Krah, A. Said, and R. Myklebust, 2016a, Pre-breakup magmatism on the Vøring Margin: Insight from new sub-basalt imaging and results from Ocean Drilling Program Hole 642E: Tectonophysics, 675, 258-274, doi: 10.1016/j.tecto.2016.02.037.

Abdelmalak, M. M., S. Planke, J. I. Faleide, D. A. Jerram, D. Zastrozhnov, S. Eide, and R. Myklebust, 2016b, The development of volcanic sequences at rifted margins: New insights from the structure and morphology of the Vøring Escarpment, mid-Norwegian Margin: Journal of Geophysical Research, Solid Earth, 121, 5212-5236, doi: 10.1002/2015JB012788.

Ball, M., H. Pinkerton, and A. J. L. Harris, 2008, Surface cooling, advection and the development of different surface textures on active lavas on Kilauea, Hawai'i: Journal of Volcanology and Geothermal Research, 173, 148-156, doi: 10.1016/j.jvolgeores.2008.01.004.

Batiza, R., and J. D. White, 2000, Submarine lavas and hyaloclastite, in Sigurdsson, H., B. Houghton, H. Rymer, J. Stix, and S. McNutt, eds., Encyclopedia of volcanoes: Academic Press, 361-381.

Berndt, C., S. Planke, E. Alvestad, F. Tsikalas, and T. Rasmussen, 2001, Seismic volcanostratigraphy of the Norwegian Margin: Constraints on tectonomagmatic break-up processes: Journal of the Geological Society, 158, 413-426, doi: 10.1144/jgs.158.3.413.

Cannon, E. C., and R. Bürgmann, 2001, Prehistoric fault offsets of the Hilina fault system, south flank of Kilauea Volcano, Hawaii: Journal of Geophysical Research, 106, 4207-4219, doi: 10.1029/2000JB900412.

Ebinghaus, A., A. J. Hartley, D. W. Jolley, M. Hole, and J. M. Millett, 2014, Lava-sediment interaction and drainagesystem development in a large igneous province: Columbia River Flood Basalt Province, Washington State, USA: Journal of Sedimentary Research, 84, 1041-1063, doi: 10.2110/jsr.2014.85.

Eide, C. H., N. Schofield, D. A. Jerram, and J. A. Howell, 2017, Basin-scale architecture of deeply emplaced sill complexes: Jameson Land, East Greenland: Journal of the Geological Society, 174, 23-40, doi: 10.1144/ jgs2016-018.

Eldholm, O., J. Thiede, and E. Taylor, 1989, Evolution of the Vøring volcanic margin: Proceedings of the Ocean Drilling Program, Scientific Results 104, 1033-1065.

Eldholm, O., J. Thiede, E. Taylor, and S. S. Party, 1987, Summary and preliminary conclusions: Proceedings of the Ocean Drilling Program, Initial Report 104, 751-771.

Fink, J. H., and R. C. Fletcher, 1978, Ropy pahoehoe: Surface folding of a viscous fluid: Journal of Volcanology and Geothermal Research, 4, 151-170, doi: 10.1016/ 0377-0273(78)90034-3.

Gregg, T. K., J. H. Fink, and R. W. Griffiths, 1998, Formation of multiple fold generations on lava flow surfaces: Influence of strain rate, cooling rate, and lava composition: Journal of Volcanology and Geothermal Research, 80, 281-292, doi: 10.1016/S0377-0273(97)00048-6. 
Hamilton, C. W., S. A. Fagents, and T. Thordarson, 2010, Explosive lava-water interactions II: Self organization processes among volcanic rootless eruption sites in the 1783-1784 Laki lava flow, Iceland: Bulletin of Volcanology, 72, 469-485, doi: 10.1007/s00445-009-0331-5.

Hinz, K., 1981, Hypothesis on terrestrial catastrophes: Wedges of very thick oceanward dipping layers beneath passive margins - Their origin and palaeoenvironement significance: Geologisches Jahrbuch, 22, 345-363.

Hon, K., J. Kauahikaua, R. Denlinger, and K. Mackay, 1994, Emplacement and inflation of pahoehoe sheet flows: Observations and measurements of active lava flows on Kilauea Volcano, Hawaii: Geological Society of America Bulletin, 106, 351-370, doi: 10.1130/0016-7606(1994) 106<0351:EAIOPS>2.3.CO;2.

Japsen, P., M. S. Andersen, L. O. Boldreel, R. Waagstein, R. S. White, and M. Worthington, 2004, Seismic and petrophysical properties of Faroe Islands basalts: The SeiFaBa project: Geological Survey of Denmark and Greenland Bulletin, 4, 53-65.

Jerram, D. A., 2002, Volcanology and facies architecture of flood basalts, in Menzies, M. A., S. L. Klemperer, C. J. Ebinger, and J. Baker, eds., Magmatic Rifted Margins: Geological Society of America Special Paper 362, 119-132.

Jerram, D. A., 2015, Hot rocks and oil: Are volcanic margins the new frontier?: Elsevier R\&D Solutions for Oil and Gas, Exploration \& Production, https://www.elsevier .com/_data/assets/pdf_file/0008/84887/ELS_GeofacetsVolcanic-Article_Digital_r5.pdf, accessed June 2016.

Jerram, D. A., and O. Robbe, 2001, Building a 3-D model of a flood basalt: An example from the Etendeka, NW Namibia: Visual Geosciences, 6, 1-8, doi: 10.1007/ s10069-001-0001-z.

Jerram, D. A., R. T. Single, R. W. Hobbs, and C. E. Nelson, 2009, Understanding the offshore flood basalt sequence using onshore volcanic facies analogues: An example from the Faroe-Shetland basin: Geological Magazine, 146, 353-367, doi: 10.1017/S0016756809005974.

Millett, J. M., M. J. Hole, D. W. Jolley, N. Schofield, and E. Campbell, 2015, Frontier exploration and the North Atlantic Igneous Province: New insights from a $2.6 \mathrm{~km}$ offshore volcanic sequence in the NE Faroe-Shetland Basin: Journal of the Geological Society, 173, 320 336, doi: 10.1144/jgs2015-069.

Nehyba, S., and D. Nyvlt, 2015, "Bottomsets" of the lava-fed delta of James Ross Island Volcanic Group, Ulu Peninsula, James Ross Island, Antarctica: Polish Polar Research, 36, 1-24, doi: 10.1515/popore-2015-0002.

Nelson, C. E., D. A. Jerram, and R. W. Hobbs, 2009, Flood basalt facies from borehole data: Implications for prospectivity and volcanology in volcanic rifted margins: Petroleum Geoscience, 15, 313-324, doi: 10.1144/ 1354-079309-842.

Nelson, C. E., D. A. Jerram, R. W. Hobbs, R. Terrington, and H. Kessler, 2011, Reconstructing flood basalt lava flows in three dimensions using terrestrial laser scanning: Geosphere, 7, 87-96, doi: 10.1130/GES00582.1.

Noguchi, R., Á. Höskuldsson, and K. Kurita, 2016, Detailed topographical, distributional, and material analyses of rootless cones in Myvatn, Iceland: Journal of Volcanology and Geothermal Research, 318, 89-102, doi: 10 .1016/j.jvolgeores.2016.03.020.

Opheim, J. A., and A. Gudmundsson, 1989, Formation and geometry of fractures, and related volcanism, of the Krafla fissure swarm, northeast Iceland: Geological Society of America Bulletin, 101, 1608-1622, doi: 10.1130/ 0016-7606(1989)101<1608:FAGOFA>2.3.CO;2.

Planke, S., E. Alvestad, and O. Eldholm, 1999, Seismic characteristics of basaltic extrusive and intrusive rocks: The Leading Edge, 18, 342-348, doi: 10.1190/1.1438289.

Planke, S., and C. Berndt, 2007, Apparatus for seismic measurements. U.S. Patent 7.221.620.

Planke, S., T. Rasmussen, S. S. Rey, and R. Myklebust, 2005, Seismic characteristics and distribution of volcanic intrusions and hydrothermal vent complexes in the Vøring and Møre basins, in A. G. Doré, and B. A. Vining, eds., Petroleum geology: North-West Europe and Global Perspectives-Proceedings of the 6th Petroleum Geology Conference: Geological Society, 833-844.

Planke, S., H. Svensen, R. Myklebust, S. Bannister, B. Manton, and L. Lorenz, 2015, Geophysics and remote sensing, Advances in Volcanology: Springer, 1-16.

Planke, S., P. A. Symonds, E. Alvestad, and J. Skogseid, 2000, Seismic volcanostratigraphy of large-volume basaltic extrusive complexes on rifted margins: Journal of Geophysical Research, 105, 19335-19351, doi: 10.1029/ 1999JB900005.

Posamentier, H. W., R. J. Davies, J. A. Cartwright, and L. Wood, 2007, Seismic geomorphology - An overview: Geological Society, London, Special Publications 277, 1.

Reynolds, P. R., R. J. Brown, T. Thordarson, E. Llewellin, and K. Fielding, 2015, Rootless cone eruption processes informed by dissected tephra deposits and conduits: Bulletin of Volcanology, 77, 72, doi: 10.1007/s00445-015-0958-3.

Schiffman, P., R. J. Watters, N. Thompson, and A. W. Walton, 2006, Hyaloclastites and the slope stability of Hawaiian volcanoes: Insights from the Hawaiian Scientific Drilling Project's 3-km drill core: Journal of Volcanology and Geothermal Research, 151, 217-228, doi: 10.1016/j .jvolgeores.2005.07.030.

Schofield, N., S. Holford, J. M. Millett, D. Brown, D. R. Jolley, S. Passey, D. Muirhead, C. Grove, C. Magee, J. Murray, and M. Hole, 2015, Regional magma plumbing and emplacement mechanisms of the Faroe-Shetland Sill Complex: Implications for magma transport and petroleum systems within sedimentary basins: Basin Research, 29, 41-63, doi: 10.1111/bre.12164.

Schofield, N., D. A. Jerram, S. Holford, S. Archer, N. Mark, J. Hartley, A. Howell, D. Muirhead, P. Green, D. Hutton, and C. Stevenson, 2016, Sills in sedimentary basins and 
petroleum systems: Advances in Volcanology, Springer Berlin Heidelberg, online first.

Schofield, N., and D. W. Jolley, 2013, Development of intrabasaltic lava-field drainage systems within the FaroeShetland Basin: Petroleum Geoscience, 19, 273-288, doi: 10.1144/petgeo2012-061.

Self, S., T. Thordarson, L. Keszthelyi, G. P. L. Walker, K. Hon, M. T. Murphy, P. Long, and S. Finnemore, 1996, A new model for the emplacement of Columbia River basalts as large, inflated pahoehoe lava flow fields: Geophysical Research Letters, 23, 2689-2692, doi: 10.1029/ 96GL02450.

Single, R. T., and D. A. Jerram, 2004, The 3D facies architecture of flood basalt provinces and their internal heterogeneity: Examples from the Palaeogene Skye Lava Field: Journal of the Geological Society, 161, 911-926, doi: 10.1144/0016-764903-136.

Skilling, I. P., 2002, Basaltic pahoehoe lava-fed deltas: Largescale characteristics, clast generation, emplacement processes and environmental discrimination: Geological Society, London, Special Publications 202, 91-113.

Smith, J. R., A. Malahoff, and A. N. Shor, 1999, Submarine geology of the Hilina slump and morpho-structural evolution of Kilauea volcano, Hawaii: Journal of Volcanology and Geothermal Research, 94, 59-88, doi: 10.1016/ S0377-0273(99)00098-0.

Stevenson, J. A., N. C. Mitchell, N. Cassidy, and H. Pinkerton, 2011, Widespread inflation and drainage of a pāhoehoe flow field: The Nesjahraun, Pingvellir, Iceland: Bulletin of Volcanology, 74, 15-31, doi: 10.1007/ s00445-011-0482-z.

Thompson, K., 2005, Extrusive and Intrusive magmatism in the North Rockall Trough, in Dore, A. G., and B. A. Vining, eds., North-West Europe and Global Perspectives: Proceedings of the 6th Petroleum Geology Conference, Geological Society, London, 1621-1630.

Thompson, T. J., and N. Schofield, 2008, Lithological and structural controls on the emplacement and morphology of sills in sedimentary basins: Geological Society, London, Special Publications, 302, 31-44.

Vail, P. R., and R. M. Mitchum, 1977, Seismic stratigraphy and global changes of sea level. I: Overview: Memoir American Association of Petroleum Geologists, 22, $51-52$.

Watton, T. J., S. Cannon, R. J. Brown, D. A. Jerram, and B. L. Waichel, 2014, Using formation micro-imaging, wireline $\operatorname{logs}$ and onshore analogues to distinguish volcanic lithofacies in boreholes: Examples from Palaeogene successions in the Faroe-Shetland Basin, NE Atlantic: Geological Society, London, Special Publications 397, 173-192.

Watton, T. J., D. A. Jerram, T. Thordarson, and R. J. Davies, 2013, Three-dimensional lithofacies variations in hyaloclastite deposits: Journal of Volcanology and Geothermal Research, 250, 19-33, doi: 10.1016/j.jvolgeores .2012.10.011.
Wright, K. A., R. J. Davies, D. A. Jerram, J. Morris, and R. Fletcher, 2012, Application of seismic and sequence stratigraphic concepts to a lava-fed delta system in the Faroe-Shetland Basin, UK and Faroes: Basin Research, 24, 91-106, doi: 10.1111/j.1365-2117.2011.00513.x.

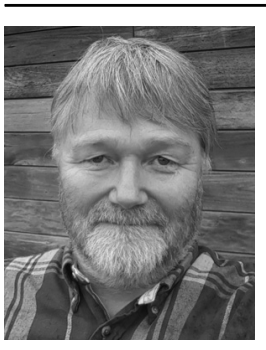

Sverre Planke received a B.S. (1985) in geological engineering and an M.S. (1987) in geophysics from the University of Utah and a Ph.D. (1993) in geology from the University of Oslo. He is the CEO of VBPR and an adjunct professor at CEED, University of Oslo, Norway. He is a geoscientist with research focus on the processes and structure of volcanic rifted margins and volcanic basins based on integrated geologic, geophysical, and theoretical methods. He is a cofounder of VBPR (1999) and P-Cable 3D Seismic (2007).

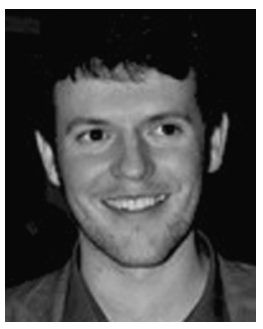

John M. Millett received a first-class B.S. Hons (2010) in geology and petroleum geology from the University of Aberdeen and a Ph.D. (2014). He works for VBPR AS and holds an Honorary Research Fellow position at the University of Aberdeen. He is a member of the Mineralogical Society and the VMSG committee. He has wide experience in volcanic basins with expertise in igneous geochemistry, stratigraphy, petrophysics, borehole analysis, and petroleum systems.

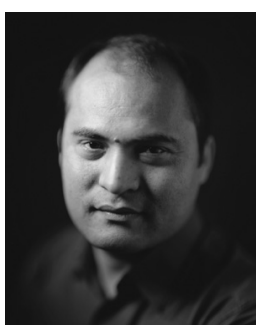

Dwarika Maharjan received an undergraduate degree (2005) in geoscience from Tribhuwan University, Nepal, and a master's degree (2011) in geoscience from the University of Oslo, Norway. His geologic career began in 2011, with Volcanic Basin Petroleum Research in Oslo, Norway. He has been actively involved in seafloor sampling projects (offshore sampling operations and reporting), and he is working on 2D and 3D seismic data interpretation and data management for multiclient and consulting projects.

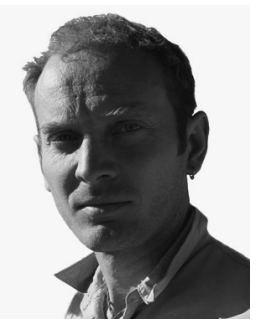

Dougal Jerram is the director of DougalEARTH Ltd. (www.dougalearth .com), and prof II at the Centre for Earth Evolution and Dynamics, University of Oslo. He is an award-winning earth scientist (Geological Society Murchison Fund 2006) and has worked for many years on projects that link academia and industry as an expert in volcanic rocks and volcanic margins. With many publications, and as an author of books, he also undertakes science 
outreach activities through the media. The most recent major venture is called Volcanic Margin Petroleum Prospectivity (VMAPP), which is a multiclient project undertaken with VBPR and TGS, looking at our state-of-the-art understanding of volcanics in the petroleum context.

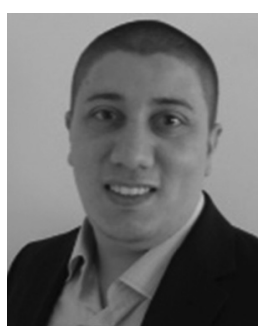

Mohamed Mansour Abdelmalak is a researcher in CEED (Norway) and an earth scientist Ph.D. since 2010 (in the Geodynamic Laboratory at Le Mans University, France) with a broad background in structural geology, tectonic, sedimentology, seismic interpretation, and cartography. He is an author of several scientific papers and international presentations on the mapping/determination of tectonic and structural evolution of volcanic margins, thermal evolution, and characterization of sedimentary basin and experimental modeling. His research experience includes a multidisciplinary approach to study the North Atlantic rifted margins using a range of techniques going from the intrusion scale to basin/crustal scale such as seismic interpretation, ArcGIS mapping, structural geology, tectonics, basin analysis, and petroleum geology.

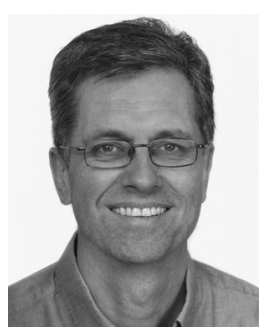

Audun Groth received a Cand. Scient. degree (1985) in geology and geophysics from the University of Oslo. He is working as a specialist in seismic interpretation and visualization for Statoil ASA in Norway.

Biographies and photographs of the other authors are not available. 